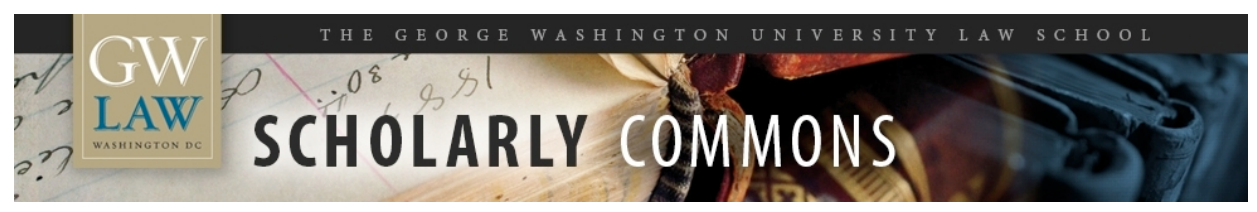

\title{
Second Amendment: Not Constitutional Dysfunction, But Necessary Safeguard
}

\author{
Robert J. Cottrol \\ George Washington University Law School, bcottrol@law.gwu.edu
}

Follow this and additional works at: https://scholarship.law.gwu.edu/faculty_publications

Part of the Law Commons

\section{Recommended Citation}

Cottrol, Robert J., Second Amendment: Not Constitutional Dysfunction, But Necessary Safeguard (2014). Robert J. Cottrol, Second Amendment: Not Constitutional Dysfunction but Necessary Safeguard, 94 B.U. L. Rev. 835 (2014).; GWU Law School Public Law Research Paper No. 2019-30; GWU Legal Studies Research Paper No. 2019-30. Available at SSRN: https://ssrn.com/abstract=3403105

This Article is brought to you for free and open access by the Faculty Scholarship at Scholarly Commons. It has been accepted for inclusion in GW Law Faculty Publications \& Other Works by an authorized administrator of Scholarly Commons. For more information, please contact spagel@law.gwu.edu. 


\title{
SECOND AMENDMENT: NOT CONSTITUTIONAL DYSFUNCTION BUT NECESSARY SAFEGUARD
}

\author{
ROBERT J. COTTROL*
}

When Jim Fleming asked me to participate in this Symposium, and more specifically to be part of the Second Amendment panel, I must confess that I was a bit puzzled. There are many parts of our political and constitutional system that are arguably dysfunctional, meaning that our late-eighteenth century Constitution prevents the achievement of policy results that are desirable in our early-twenty-first century present. I do not see, however, the Second Amendment as one of those constitutional features. As a result, this Essay challenges two assumptions: first, that the Second Amendment historically has provided much of a barrier to a desirable policy result, radical gun control or perhaps more accurately gun prohibition; and second, that such a result is indeed desirable.

For the first proposition, it is fair to say that until the 2008 case of District of Columbia v. Heller ${ }^{1}$ and its 2010 companion McDonald v. City of Chicago, ${ }^{2}$ the federal courts had been essentially absent from the business of looking at the Second Amendment and seriously asking what protection it provides, as well as what limitations it places on individuals' rights to have arms. This was not, as some have erroneously insisted, because there was some universal agreement that the Amendment, which speaks of a well-regulated militia and the right of the people to keep and bear arms, applied only to militias and not to individuals in their private capacities. Before Heller, the Supreme Court had recognized the individual nature of the right to arms on those rare occasions when it had referenced this right or the right to have arms generally - including Chief Justice Taney's discussion of the rights of citizens and the implications

* Robert J. Cottrol, Harold Paul Green Research Professor of Law and Professor of History and Sociology, The George Washington University. This Essay was delivered at the Symposium titled America's Political Dysfunction: Constitutional Connections, Causes, and Cures, at Boston University on November 15-16, 2013. The Author would like to acknowledge the research assistance of The George Washington University Law School students Rebecca Szucs, Benjamin Anders, and Shawn Greene. I would also like to thank Bob Dowlut, Ray Diamond and Nick Johnson for reading drafts of this Essay and making helpful suggestions. It should be noted that the style of this Essay is in the format of the talk that was delivered, or at least as it was meant to be delivered.

1554 U.S. 570, 591 (2008) (finding that the Second Amendment guarantees an individual right to bear arms).

2130 S. Ct. 3020, 3023 (2010) (holding that the Second Amendment applies to the states by virtue of the Fourteenth Amendment). 
of citizenship in Dred Scott; Chief Justice Waite's examination of the distinctions between federal restrictions and state and private action in Cruikshank; Justice Wood's refusal to apply the Second Amendment to state action in Presser v. Illinois; and Justice McReynolds's opinion in United States v. Miller, which is best read as recognizing an individual's right to have arms while also reaffirming the by-then long recognized principle that some arms are within the ambit of constitutional protection and others are not. ${ }^{3}$ The individual nature of the right was a largely unquestioned principle in the Court's jurisprudence. Indeed as late as 1961 in Justice John Marshal Harlan II's dissent in Poe v. Ullman, it was considered rather unremarkable. ${ }^{4}$

Still the Second Amendment would not receive definitive recognition, including a recognition that it provided real limitations on firearms regulation, until Heller, some 217 years after its initial adoption. This lack of judicial engagement occurred for two reasons. The first reason is the intellectually haphazard way the Court has gone about the business of incorporation or applying the Bill of Rights to the states through the Fourteenth Amendment. There is strong evidence that the drafters and ratifiers of the Fourteenth Amendment intended and understood that, by the passage of the Fourteenth Amendment, they were forever altering the old federalism in which the federal Constitution had little or nothing to say concerning the rights of the citizen in the face of state power. ${ }^{5}$ The post-Fourteenth Amendment Court early on

3 See United States v. Miller, 307 U.S. 174, 178 (1939); Presser v. Illinois, 116 U.S. 252, 257 (1886); United States v. Cruikshank, 92 U.S. 542, 553 (1876); Dred Scott v. Sandford, 60 U.S. (19 How.) 393, 417 (1857).

${ }^{4}$ Poe v. Ullman, 367 U.S. 497, 543 (1961) (Harlan, J., dissenting). Justice Harlan included in his dissent a discussion of the right to have arms as part of the group of rights guaranteed to American citizens. He did so to advise his fellow Justices that the rights specifically enumerated in the Bill of Rights do not exhaust the constitutionally protected rights of Americans. Although he wrote for the dissent in Poe, a case involving the state of Connecticut's then-existing prohibition on the sale of contraceptives, his language would be repeated in subsequent cases involving the right to privacy. What is important for our purposes is that Justice Harlan felt completely comfortable simply listing the right to have arms along with other enumerated rights without indicating any need to discuss the right to have arms as being somehow confined to those who were members of the militia or involved in militia service. Instead Harlan simply discussed the right as one of the rights generally safeguarded to the American people at large:

[T] he full scope of the liberty guaranteed by the Due Process Clause cannot be found in or limited by the precise terms of the specific guarantees elsewhere provided in the Constitution. This "liberty" is not a series of isolated points pricked out in terms of the taking of property; the freedom of speech, press, and religion; the right to keep and bear arms; the freedom from unreasonable search and seizures; and so on. Id.

${ }^{5}$ Cong. Globe, 39th Cong., 1st Sess. 1291 (Mar. 9, 1866) (statement of Rep. John Bingham) (stating that the Amendment would be "enforced everywhere" and "would arm Congress with the power to compel obedience to the oath [to obey the Constitution] and punish all violations by State officers of the bill of rights"); see also Richard L. Aynes, 
rejected the new constitutional order and in many ways, McDonald being but the latest example ${ }^{6}$ has spent nearly a century and a half trying to revive the constitutional goal that Jonathan Bingham and Jacob Howard ${ }^{7}$ tried to advance in $1866 . .^{8}$ In any event, much of the jurisprudence denying Second Amendment claims alleging infringement of the right to keep and bear arms, was rooted in the view that the Reconstruction Amendment did not protect the citizen from state restrictions on the use of firearms. ${ }^{9}$ As most restrictions historically, and indeed in the present, come from state legislatures and not Congress, that limitation was of critical importance.

And there was, of course, another reason that the courts became increasingly unwilling to apply the Second Amendment and seriously examine the extent to which it posed limitations on firearms regulations. Particularly after the turmoil of the 1960s and the growth of the modern gun control movement, which has always had a strong prohibitionist contingent in its ranks, more and more jurists had come to agree with former Harvard Law School Dean Roscoe Pound's view that the Second Amendment was simply too dangerous to be recognized in modern times. ${ }^{10}$ Many thought that it would be best, if the Amendment could not be repealed outright, that the provision be subject to judicial nullification. ${ }^{11}$ Lower federal courts increasingly engaged in such nullification, using numerous variations of the idea that the Amendment only protected the right of states to have militias, or only protected individuals who were actively in militia service. ${ }^{12}$ The exact details of what was protected or

Enforcing the Bill of Rights Against the States: The History and the Future, $18 \mathrm{~J}$. CONTEMP. LEGAL IsSUES 77, 86 (2009) ("All seem to agree that Senator Jacob Howard's speech in the Senate indicated that one of the purposes of the Amendment was to enforce the Bill of Rights against the states.").

${ }^{6}$ See McDonald, 130 S. Ct. at 3020.

7 John Bingham and Jacob Howard were the drafters of the Fourteenth Amendment. Aynes, supra note 5, at 140.

${ }^{8}$ Wayne D. Moore, The Fourteenth Amendment's Initial Authority: Problems of Constitutional Coherence, 13 TEMP. POL. \& CIV. RTS. L. REV. 515, 523 (2004) (explaining how the Slaughter-House Cases and Civil Rights Cases can be viewed as efforts by the Supreme Court to avoid interpreting the Fourteenth Amendment as altering the past constitutional order).

${ }^{9}$ See Bethany Jones, Monkey See, Monkey Do? The Establishment Clause as Possibly Illustrative of the Second Amendment's Incorporation, 74 BROOK. L. REV. 509, 522 (2009) (explaining that the Court's refusal to examine the Second Amendment and its silence on the issue indicated that the Second Amendment was not incorporated by the Fourteenth Amendment). Because of this silence, most lower courts decided that the Second Amendment was not incorporated by the Fourteenth Amendment.

${ }^{10}$ Roscoe Pound, From the Revolution to the Constitution, in THE DEVelopment of CONSTITUTIONAL GUARANTEES OF LIBERTY 82, 89-91 (1957).

${ }^{11}$ Id.

12 See, e.g., Hickman v. Block, 81 F.3d 98, 102 (9th Cir. 1996) ("Because the Second Amendment guarantees the right of the states to maintain armed militia, the states alone 
how a right of the people became, in effect, a right of the states, or a right of a government agency or government agency members, were somewhat hazy. But the important thing, we were assured, was that no individual could contest an arms infringement, however severe, on the grounds that the right to keep and bear arms was imperiled. The lower federal courts' judicial nullification of the Second Amendment in the second half of the twentieth century is similar to the federal judiciary's treatment of the Fourteenth Amendment's Equal Protection Clause and the Fifteenth Amendment's protection for the right to vote regardless of race in the early decades of the twentieth century. In both instances the federal judiciary effectively nullified an intended constitutional protection for a civil right because it believed this was was the better policy choice. ${ }^{13}$

Let me fast forward a bit (for those of us who still have a VHS player somewhere at home). What I just described was the past. Heller and McDonald are our present reality. The Court has recognized an individual right by a bare five-four majority. It is clear that some members of the Court not only dissented from that result, but are eager to reverse it. Justice Ginsburg, for example, has been particularly active in speaking out against the two Second Amendment decisions. She recently articulated a remarkable version of the collective rights theory, stating that the Second Amendment was put in the Constitution in part because the infant American Republic could not afford an army and had to rely on a broad-based militia for national defense. ${ }^{14}$ Now that we can afford an army, and one might indeed add an Air Force, Navy, Marine Corps, and Coast Guard, as well, Justice Ginsburg argues that the Second Amendment is obsolete and no longer protects the right to have arms. ${ }^{15}$ Justice Ginsburg did not explain, however, why a nation that could not afford an army and had to rely on a broad based militia for its survival had to be reminded, in a constitutional amendment, no less, not to disarm its only means of defense.

stand in the position to show legal injury when this right is infringed."); Love v. Pepersack, 47 F.3d 120, 123 (4th Cir. 1995) ("The Second Amendment does not apply to the states."); Sandidge v. United States, 520 A.2d 1057, 1058 (D.C. 1987) ("[The Second Amendment] protects a state's right to raise and regulate a militia by prohibiting Congress from enacting legislation that will interfere with that right. [lt] says nothing that would prohibit a state from restricting the use or possession of weapons . . .."); Cases v. United States, 131 F.2d 916, 921 (1st Cir. 1942) ("Whatever rights in this respect the people may have depend upon local legislation; the only function of the Second Amendment being to prevent the federal government and the federal government only from infringing that right.").

13 William N. Eskridge, Jr., Some Effects of Identity-Based Social Movements on Constitutional Law in the Twentieth Century, $100 \mathrm{MICH}$. L. REV. 2062, 2250 (2002) (remarking that in the beginning of the twentieth century the Supreme Court had effectively nullified the Equal Protection Clause).

14 Interview by John Hockenberry with Justice Ruth Bader Ginsburg (Sept. 16, 2013) (transcript archived at http://perma.cc/SW5Q-26WT) (including Justice Ginsburg's explanation of the origins and purpose of the Second Amendment).

${ }^{15}$ Id. (describing the Second Amendment as obsolete). 
Nor did she explain why the right in the Second Amendment was termed a "right of the people" when what she describes is a power of the government to maintain a militia so long as it deemed one to be necessary. ${ }^{16}$

But in any event we have an individual right to keep and bear arms recognized by the Supreme Court and now applied by the lower federal and state courts. So how much of a constitutional impediment to gun control has this new constitutional reality been to date?

The answer as a general matter is not very much. Courts appear to be applying, at most, a somewhat weak intermediate scrutiny, perhaps even a rational basis plus standard, to firearms restrictions, except in cases of outright prohibitions, such as the circumstances that gave rise to Heller and McDonald. Although Justice Scalia's opinion in Heller, with its discussion of the constitutionality of restrictions on carrying arms in sensitive places, certainly suggests that the Second Amendment protects a right to bear as well as a right to keep, the lower federal courts have not analyzed prohibitions or severe restrictions on the right to carry with particularly rigorous scrutiny. ${ }^{17}$ The notable exception is Judge Posner's opinion in Moore v. Madigan, ${ }^{18}$ where the Seventh Circuit voided Illinois' total prohibition on the carrying of handguns. ${ }^{19}$ The Second Circuit has upheld financially prohibitive licensing fees and extensive waiting periods, known to last as long as six months, for a license to

16 Id.

17 District of Columbia v. Heller, 554 U.S. 570, 592 (2008) (finding that the Second Amendment confers an "individual right to possess and carry weapons" (emphasis added)); see, e.g., Kachalsky v. Cnty. of Westchester, 701 F.3d 81, 101 (2d Cir. 2012) (ruling that the New York statute that prevented individuals from obtaining full-carry licenses did not violate the Second Amendment); People v. Ellison, $128 \mathrm{Cal}$. Rptr. 3d 245, 250 (Cal. Ct. App. 2011) (holding that California's law prohibiting carrying concealed weapons did not violate the Second Amendment); In re Wheeler, 81 A.3d 728, 757 (N.J. Super. Ct. App. Div. 2013) (finding the New Jersey statute requiring a "justifiable need" to carry a weapon did not violate the Second Amendment).

18702 F.3d 933 (7th Cir. 2012).

${ }^{19} I d$. at 933 (deciding that an Illinois statute that prohibited the carrying of guns in public was unconstitutional). As this Essay was in the final editing stages, a three judge panel of the Ninth Circuit Court of Appeals on February 13, 2014 held that the Second Amendment included the right to carry an operable handgun outside the home for the purposes of selfdefense and that San Diego County's requirement that a person had to show sufficiently pressing need for self-defense before a permit to be carried would be issued infringed the Second Amendment right to bear arms. It was not clear at the time this Essay went to press whether there would be on en banc reconsideration of the ruling. See Peruta v. Cnty. of San Diego, No. 10-56971, 2014 WL 555862 (9th Cir. Feb. 13, 2014). On February 27, 2014 the State of California filed a Motion to Intervene asking the Ninth Circuit to allow the state to file for an en banc hearing because the Sheriff of San Diego County had declined to do so. Motion to Intervene for Kamala D. Harris, Attomey General of California, Peruta, No. 1056971,2014 WL 555862. 
own a handgun in the home in New York City. ${ }^{20}$ The Fourth Circuit has found reasonable Maryland's system of granting permits to carry firearms that leaves the issuance of such firearms solely to the discretion of police officials. ${ }^{21}$ No federal court has seriously looked at restrictions on so-called assault weapons in light of Heller and McDonald to ascertain if these weapons should be required to satisfy some sort of special dangerousness test, which would presumably be necessary for a prohibition on a weapon in light of a right to bear arms. Nor have the courts seriously examined the extent to which such weapons might be protected in light of a residual militia reading of the Second Amendment, even though Heller, unlike its predecessor Miller, placed individual self-defense, and not the idea of the broad-based citizen's militia, at the core of the protection afforded by the Second Amendment.

So at least to date the judicially recognized version of the Second Amendment stands for the proposition that local, state, or federal governments cannot have a total prohibition on all - or perhaps the most commonly owned rifles, pistols, and shotguns without a more detailed elaboration of which specific weapons might be included in the protected categories. Also left largely unresolved is whether or not the Second Amendment right includes a right to carry arms for protection. I should make a slight detour here. So far I have been speaking of the Second Amendment as a vehicle for judicial protection for the right to arms. It should be acknowledged that the Second Amendment has long served as something of a political and moral check on firearms prohibition on the part of the political branches of government. At least forty-four states have provisions in their constitutions protecting the right to keep and bear arms. ${ }^{22}$ Twenty-one of these provisions were enacted or reenacted in the twentieth century. ${ }^{23}$ Congress's repeated support for the principle that the Constitution protects an individual's right to arms is shown, most recently, in the Firearms Owners' Protection Act of 1986 which, among other things, provides federal protection from state action for firearms owners traveling through states with restrictive firearms legislation. ${ }^{24}$ Public opinion continued to support an individualistic reading of the Second Amendment even

${ }^{20}$ Kwong v. Bloomberg, 723 F.3d 160, 168 (2d Cir. 2013) (finding New York's licensing fees to be constitutional).

${ }^{21}$ Woollard v. Gallagher, 712 F.3d 865, 881 (4th Cir. 2013) (holding that the Maryland statute requiring a "good and substantial reason" in order to obtain a gun license was constitutional).

${ }^{22}$ Eugene Volokh, State Constitutional Rights to Keep and Bear Arms, 11 TEx. REV. L. \& PoL. 191, 192 (2006) (asserting that forty-four states have constitutions with the right to bear arms).

${ }^{23}$ Id. at 192-205 (listing each state's constitutional provision about the right to bear arms and the dates of enactment or re-enactment).

24 Firearms Owners' Protection Act of 1986, Pub. L. No. 99-308, § 107(a), 100 Stat. 449, 460 (stating that any person who is permitted to own a firearm should be entitled to transport the unloaded firearm in interstate commerce regardless of the state's firearm laws). 
in the 1970 s and 80 s, when the judiciary was most beguiled by the militia-only alternative. ${ }^{25}$

But the judiciary now recognizes the individual rights view of the Amendment, and provides a protection for the citizen's right to have arms, even if that protection is quite modest. The modern gun control movement in its salad days envisioned a regime of severe restrictions on firearms ownership. ${ }^{26}$ There were efforts at handgun prohibition enacted in the District of Columbia, ${ }^{27}$ Chicago, and a few other villages in Illinois, ${ }^{28}$ but these failed more broadly even in a referendum in the 1970s in liberal Massachusetts. ${ }^{29}$ The movement also sought strict limits on the ownership of rifles and shotguns. But ordinary, commonly owned rifles, pistols, and shotguns (still largely undefined) are now recognized as constitutionally protected. The judiciary is now prepared to say that the Constitution prohibits that which the gun control movement has, with the exception of a few outlier precincts, been politically unable to achieve over the last forty years.

So where is the constitutional dysfunction? Why is there a calling forth of the volunteer brigade of academic commentators to put out a constitutional fire of exceedingly small dimensions?

I suspect one can only look at the Second Amendment as an example of constitutional dysfunction if one accepts the fundamental postdates of the modern gun control movement as it emerged since the late 1960s. Briefly stated, the United States is a disturbing outlier among modern industrial nations because of widespread ownership of guns, particularly for selfdefense. ${ }^{30}$ Even more disturbing, at least for some, many of these weapons were and are of military vintage, although not quite the weapons currently used by the Armed Forces. Their presence hints at a preparation for perhaps a war of all against all, or of some against the government. Preparation for armed selfdefense, perhaps for insurrection itself, is disturbing. What happened to the

25 JAMES D. WRIGHT ET AL., UNDER the GUN: WeAPONS, CRIME, AND VIOLENCE IN AMERICA 138-39 (1983).

${ }^{26}$ GARY KLECK, TARGETING GUNS: FirearmS AND THEIR CONTROL 11-14 (1997).

${ }^{27}$ District of Columbia v. Heller, 554 U.S. 570, 575 (2008) (describing the District of Columbia's law prohibiting the possession of handguns).

${ }^{28}$ McDonald v. City of Chi., $130 \mathrm{~S}$. Ct. 3020, 3026 (2010) (holding that the laws of Chicago, Illinois and Oak Park, Illinois, both of which prohibited the possession of handguns, violated the Second Amendment).

${ }^{29}$ Robert J. Cahall, Local Gun Control Laws After District of Columbia v. Heller: Silver Bullets or Shooting Blanks? The Case for Strong State Preemption of Local Gun Control Laws, 7 Rutgers J.L. \& PUB. Pol'y 359, 387 n.95 (2010) (noting that a Massachusetts Handgun Ban Referendum was defeated in 1976).

${ }^{30}$ See Joe Van Brussel, U.S. Guns: Statistics Show America an Outlier Among Developed Countries, HuFFINGTON Post (Dec. 20, 2012), http://www.huffingtonpost.com/ 2012/12/20/us-guns-statistics-outlier_n_2331892.html, archived at http://perma.cc/HT4KMVU8. 
wise counsel we heard in political science class in our distant undergraduate incarnations that the state should have a monopoly of force? ${ }^{31}$ Are we a civilized society? What will we say to our European colleagues at international conferences?

And there is the quite realistic fear of crime and the fear that widespread availability of firearms has contributed to a high homicide rate in the United States, one that is higher than the rates in what are generally considered comparable countries, such as the nations of Western Europe, Canada, Australia, and New Zealand. ${ }^{32}$ The Second Amendment is an example of constitutional dysfunction even if it contributes only minimally to preventing serious restrictions on firearms. Proponents of severe restrictions on firearms ownership root their advocacy in part on the belief that strong restrictions on firearms ownership are likely to bring significant reductions in violent crime, particularly homicide, and that these reductions far outweigh any good that might come from individual gun ownership. For example, gun control proponents often assert that ordinary citizens are unable and unlikely to defend themselves successfully with firearms and are more likely to do harm to themselves and other innocent parties than to defend themselves effectively. ${ }^{33}$

These criminological premises, once the conventional wisdom in the firearms debate, have not stood up very well in the face of serious social science examination. For at least the first two decades of the national firearms debate, in the 1960s and 1970s, the American public was solemnly assured that decent, peaceable citizens possessing guns for self-defense were disasters waiting to happen. "A gun in the home is more likely to kill a member of the family than to defend against an intruder," we were informed. ${ }^{34}$ "Allowing citizens to carry firearms outside the home for self-protection will turn our streets into Dodge City and our parking lots into the O.K. Corral" was the frequent refrain. ${ }^{35}$ And then something happened. Starting in the 1980 s, social scientists, many who were previously neutral, and in some cases hostile, to

31 Clifford J. Rosky, Force, Inc.: The Privatization of Punishment, Policing, and Military Force in Liberal States, 36 CONN. L. REV. 879, 896 n.43 (2004) (discussing the famous phrase "monopoly of force," coined by pioneering social scientist Max Weber).

32 Gun Homicides and Gun Ownership by Country, WASH. Post (Dec. 17, 2012), http:// www.washingtonpost.com/wp-srv/special/nation/gun-homicides-ownership/table (comparing the number of homicides in various countries throughout the world and finding that, among developed countries, the United States has the greatest number of guns and the highest per capita rate of firearm-related murders).

33 Warren E. Leary, Guns in the Home; Staying Unarmed Is Safer, a New Study Finds, N.Y. TIMES, Oct. 10, 1993, $\S 4$, at 2 (discussing a study conducted by Arthur Kellerman at Emory University, which concluded that having a gun in the home makes the homeowner less safe rather than more safe).

${ }^{34}$ Robert J. Cottrol, A Liberal Democrat's Lament: Gun Control Is Racist, Sexist \& Classist, AM. ENTERPRISE, Sept. 1999, at 58, 59.

${ }^{35}$ Id. 
widespread public ownership of firearms began to put the claims of the gun control movement under an empirical lens. ${ }^{36}$ Their findings did not bring great comfort to advocates of stricter gun control. Rather their findings taken together indicated a significant, although still to be debated, amount of selfdefense by ordinary U.S. citizens with privately owned weapons. ${ }^{37}$ Evidence indicates that criminals' fear of encountering armed victims plays a major role in deterring crime, particularly violent crime, and that there is relatively little misuse of firearms on the part of people who do not have criminal records or histories of mental instability. ${ }^{38}$

I realize there are respected social scientists on both sides of the empirical debate and that space and my own training and disciplinary limitations do not permit me to review exhaustively the argument measuring each chi square and r-square test offered by the different economists, sociologists, and statisticians who have weighed in on this controversy. But the very existence of this controversy, the fact that the criminological benefits of radical gun control are far from proven, and indeed are highly contested, should cause us to approach the notion of restrictive firearms policies - and the corollary idea that the Second Amendment is some sort of constitutional infirmity that must be overcome - with all due humility and skepticism. If the criminological benefits and resulting crime reduction were uncontested and widely agreed upon, then perhaps (and I emphasize only perhaps) the case for a radical reduction in private firearm ownership and the need for the explicit or implicit repeal of the Second Amendment might be something on which we could all agree. But with the empirical case for radical gun control problematic at best, we need to ask serious questions, not only concerning promised gains, but also concerning losses that may come with a regime of radical gun control.

In terms of assessing the cost of such measures, it should first be noted that firearms prohibition would require bringing the heavy hand of the criminal justice system to bear on essentially peaceable citizens. Many of these citizens would be made criminals, not because they set about the business of trying to injure their fellow citizens, to commit robbery, rape, murder, or mayhem, but because they seek to protect themselves from those who seek such ends. The natural desire to find a means of protection would be strong, particularly in some of the nation's more violent precincts where the law has often egregiously failed in its primary duty to protect people. Some would seek and find weapons for protection, regardless of the state of the law. The promise that rigorous gun restrictions will, in a generation or so, eliminate the estimated 300

${ }^{36}$ Sociologist James D. Wright and his associates undertook one of the earliest of these empirical studies. See WRIGHT ET AL., supra note 25.

${ }^{37}$ Gary Kleck \& Marc Gertz, Armed Resistance to Crime: The Prevalence and Nature of Self-Defense with a Gun, 86 J. CRIM. L. \& CRIMINOLOGY 150, 164 (1995-1996) (asserting that there are 2.2 to 2.5 million civilian defensive gun uses on others each year, with 1.5 to 1.9 million of these incidents involving a handgun).

38 GARY KLeCK, PoINt BlanK: GuNS AND VIOLENCE IN AMERICA 130-45 (1991). 
million firearms in private hands, ${ }^{39}$ leading to a safer society for all, would be of little comfort to those who live on the mean streets of some of our more dangerous inner city neighborhoods. Many in those neighborhoods find that the law's current promise for protection is a hollow one, and that the promise of a gun free, safer future is more social science fiction than achievable reality.

Restrictions would have to be enforced with great rigor, a rigor that might very well punish more severely those who commit the malum prohibitum crime of possessing defensive weapons than those who commit what we traditionally viewed as a malum in se crime - such as burglary, robbery, rape, or assault and battery - which is inherently evil regardless of the particular jurisdiction or historical moment in which we happen to find ourselves. I recall two such examples right here in Massachusetts from when I first began teaching law at Boston College in the 1980s. One case involved a man named Sylvester Lindsey who was convicted of carrying a pistol without a license. ${ }^{40}$ Lindsey carried a pistol to protect himself from a coworker who had threatened and attacked him, and used the pistol to shoot his coworker in self-defense. Lindsey was found not guilty of assault with intent to commit murder, but was convicted of illegally carrying a pistol in violation of Massachusetts's FoxBartley statute. ${ }^{41}$ In reviewing his sentence of one year imprisonment, the Massachusetts Supreme Judicial Court agreed that, though Lindsey's possession of the pistol may very well have saved his life, the Massachusetts statute gave the court no discretion. ${ }^{42}$ The statute mandated a year in prison for the unlicensed carrying of a pistol, regardless of the defendant's needs, and regardless of the consequences of going unarmed in emergency circumstances. ${ }^{43}$

Three years later in 1989, the Boston Globe reported that a trial court gave a suspended sentence to a forty-four-year-old man who had twice committed sexual assault on an eight-year-old girl. ${ }^{44}$ Taking the most charitable possible view of the trial court judge's actions in the latter case, an admittedly hard task, we still had a monstrous state of legal affairs in Massachusetts in the late 1980s. A man who twice sexually assaults a child could have his excuses and circumstances weighed and given leniency, while a man who defends himself, and perhaps saves his life, with an illegal gun could be sent to prison. No

39 See L. Hepburn et al., The US Gun Stock: Results from the 2004 National Firearms Survey, 13 InJ. PREVENTION 15, 18, 19 (2007).

40 See Commonwealth v. Lindsey, 489 N.E.2d 666 (Mass. 1986).

${ }^{41}$ MASS. GEN. LAWS ch. 269, § 10 (1975).

42 Lindsey, 489 N.E.2d at 669 (explaining that before the one-year mandatory minimum sentence for gun possession was imposed, the Court would have had more discretion, but now an option to lower the sentence was not available).

${ }^{43} \mathrm{Id}$.

${ }^{44}$ Richard Kindleberger, Ruling in Beverly Assault Case Leaves Scars, Bos. GLOBE, Mar. 26, 1989, at 25 (explaining that a sexual assault convict is released with probation, instead of jail time). 
explanations, excuses, or mitigations can be allowed to modify the law's rigor. Before we embark on a course of far-reaching gun control, we need to ask hard questions about the extent to which such an approach will perforce create more cases like Sylvester Lindsey's, cases that result in harsh and disproportionate punishment for people who can only be deterred with draconian penalties far out of proportion to either the threat they pose to society or the inherent evil of the offense they have committed. They can only be so deterred because they rightly perceive that the alternative to being armed is to be at the mercy of the predators from whom the state has failed to protect them. Surely before we embark on such a course, we should be sure that the criminological gain is worth the moral cost.

But for some advocates of severely restrictive gun control, the virtue in such measures and in doing away with the Second Amendment lies not in a weighing of the criminological costs and benefits. Instead the new direction is desirable because it would signal an improvement in the nation's culture, a promising sign that we had joined the rest of the world's advanced nations in giving the state a monopoly of force. We are informed that such a monopoly will take us away from our atavistic past of frontier violence and racial conflict into the bright dawn of civilized nations, where disputes are peacefully resolved and conflicts settled by a benevolent and powerful state.

And yet it is this international comparison, more than perhaps any other consideration, that should give us serious pause concerning the prescriptions proffered by those who advocate the radical disarmament of the American public. The twentieth century repeatedly gave us horrifying examples of the consequences of unchecked state monopolies of force. University of Hawaii political scientist Rudolph J. Rummel, one of the leading students of democide - the mass murder of civilian populations by governments - estimated that nearly 170 million people were murdered by their own governments in the twentieth century. ${ }^{45}$ The familiar list of mass murderers - Hitler, Stalin Mao, and Pol Pot - only scratches the surface of the monsters who have gained control of national governments and have wrecked havoc on victims by the millions. ${ }^{46}$ Before we accept the notion that the state should have this monopoly of force, we need to ask ourselves some hard questions. Could the overstretched Nazi war machine have murdered between ten- and twentymillion armed and resisting Europeans while also taking on the Soviet and

${ }^{45}$ Cottrol, supra note 34, at 59 (discussing Rudolph Rummel's conclusions).

46 Id. As this Essay was in the final editing stages, the United Nations General Assembly released a disturbing new report indicating that the mass murder of civilian populations by governments emboldened by monopolies of force will continue to plague us in the twentyfirst century. In particular, the report indicates the commission of systematic crimes against humanity: "The gravity, scale and nature of these violations revealed a State that does not have any parallel in the contemporary world." U.N. Human Rights Council, Rep. of the Comm'n of Inquiry on Human Rights in the Democratic People's Republic of Kor. If 8085, 25th Sess., Mar. 3-Mar. 28, 2014, U.N. Doc. A/HRC/25/63 (Feb. 7, 2014). 
Anglo-American armies $?^{47}$ Could fifty- to seventy-thousand Khmer Rouge have butchered two- to three-million armed Cambodians? ${ }^{48}$ And perhaps most disturbing of all, why do we not ask these questions regularly and integrate them into our national debate on gun ownership? ${ }^{49}$

At one time our national leaders, including our liberal national leaders, recognized that the uniqueness of the American right to keep and bear arms was not something for which to apologize, but instead a feature of American governance from which the rest of the world might learn. Hubert Humphrey was one such national leader, who remarked:

Certainly one of the chief guarantees of freedom under any government, no matter how popular and respected, is the right of citizens to keep and bear arms. This is not to say that firearms should not be very carefully used and that definite safety rules of precaution should not be taught and enforced. But the right of citizens to bear arms is just one more guarantee against arbitrary government, one more safeguard against a tyranny which now appears remote in America, but which has historically proved to be always possible..$^{50}$

And yet I fear that in more recent decades this critical question of whether or not the state should be granted a monopoly of force has been relegated to the margins of our national discourse on this critical topic.

There is of course an argument that a population equipped with small arms would be unable to resist effectively a modern military force, with its array of armored vehicles, long-range artillery, and attack aircraft. ${ }^{51}$ While I am not totally persuaded by that argument, it is one that must give some pause to those of us who support an armed civilian population in part to resist or help resist a potentially tyrannical government. But perhaps that question should be framed less in terms of the kind of resistance that would result in the overthrow of a potentially despotic government, and more in terms of a resistance that raises the costs and consequently provides some deterrence against some of the worst

${ }^{47}$ R.J. RuMMel, DeATH By GovernMENT 4 tbl.1.2 (1994); Fred E. Katz, Implementation of the Holocaust: The Behavior of Nazi Officials, 24 COMP. STUD. SoC'Y \& HIST. 510, 511 (1982).

48 RuMmel, supra note 47.

49 This question arguably has not been raised often enough in the modern policy debate. It has, however, gained a place in the legal literature discussing the Second Amendment and the right to keep and bear arms. Sanford Levinson stressed the importance of the question in his pioneering essay on the Second Amendment. Sanford Levinson, The Embarrassing Second Amendment, 99 YALE L.J. 637, 649-52, 656-57 (1989). Legal scholars Daniel Polsby and Don B. Kates have also argued for the modern relevance of a right to arms in deterring state tyranny. See Daniel D. Polsby \& Don. B. Kates, Of Holocausts and Gun Control, 75 WASH. U. L.Q. 1237 (1997).

${ }^{50}$ Hubert Humphrey, Know Your Legislators, GuNs, Feb. 1960, at 4.

51 See Charles J. Dunlop, Revolt of the Masses: Armed Civilians and the Insurrectionary Theory of the Second Amendment, 62 TENN. L. REV. 643 (1995). 
acts that totalitarian governments are capable of committing. Perhaps we should pay more attention to one of the victims of Stalin, one of the more prolific of the monsters in human form, who slaughtered millions in the twentieth century. Writer Alexandr Solzhenitsyn's words still speak for the tens of millions who perished in the concentration camps of Central and Eastern Europe, the gulags of the Soviet Union, and the killing fields of Cambodia:

And how we burned in the camps later, thinking: What would things have been like if every Security operative, when he went out at night to make an arrest, had been uncertain whether he would return alive and had to say good-bye to his family? Or if, during periods of mass arrests, as for example in Leningrad, when they arrested a quarter of the entire city, people had not simply sat there in their lairs, paling with terror at every bang of the downstairs door and at every step on the staircase, but had understood they had nothing left to lose and had boldly set up in the downstairs hall an ambush of half a dozen people with axes, hammers, pokers or whatever else was at hand? ... The Organs would very quickly have suffered a shortage of officers and transport and, notwithstanding all of Stalin's thirst, the cursed machine would have ground to a halt! ${ }^{52}$

Some would argue that such considerations are out of place in contemporary America, with its strong democratic traditions and open access to the legislatures and the courts, and that talk of an insurrectionist dimension to the Constitution is dangerous and in itself undemocratic. And yet as Judge Alex Kozinski of the Ninth Circuit, himself the son of Holocaust survivors, reminds us, "few saw the Third Reich coming until it was too late." 53 Can we say that such a discussion must not be entertained, that we regard ourselves as forever immune from the kinds of evil forces that have befallen other nations? I certainly hope so, but should we be willing to render ourselves helpless in the belief that such can never happen here?

We should approach the notion that it cannot happen here with due humility. The United States has been spared the reign of mad dictators bent on subjugating, terrorizing, and destroying whole populations. But state tyranny

52 Aleksandr Solzhenitsyn, The Gulag ArChipelago: 1918-1956, at 13 n.5 (1973).

${ }^{53}$ Silveira v. Locyer, 328 F.3d 567, 570 (9th Cir. 2003) (denying rehearing en banc) (Kozinski, J., dissenting). Judge Kozinski's dissent harkens back to the historical tradition of looking at the Second Amendment as a defense against potential tyranny:

My excellent colleagues have forgotten these bitter lessons of history. The prospect of tyranny may not grab headlines the way vivid stories of gun crime routinely do. But few saw the Third Reich coming until it was too late. The Second Amendment is a doomsday provision, one designed for those exceptionally rare circumstances where all other rights have failed - where the government refuses to stand for reelection and silences those who protest; where courts have lost the courage to oppose, or can find no one to enforce their decrees. However improbable these contingencies may seem today, facing them unprepared is a mistake a free people get to make only once. Id. 
can come in other forms, including the deliberate refusal of authorities to protect unpopular groups from violence by hostile majorities. A number of scholars, myself included, have written about this from the perspective of the Afro-American experience, and how a right to arms played an important role in mitigating racial violence during the Jim Crow era and in providing the physical protection that enabled the voter registration efforts and other activities of civil rights workers in the South in the $1950 \mathrm{~s}$ and $1960 \mathrm{~s} .{ }^{54}$ These examples should not be disregarded as simply historical examples from a past that is now mercifully, or hopefully, far behind us. Instead they should be seen as case studies in the need for vulnerable minorities to have the means of selfdefense. The names of the minorities who might have such needs will change over time, but the principle that there is a need for the means of self-defense, that it should not be taken away, and that it is dangerous to force a people to rely solely on the state for protection, remains sound policy, and not an example of constitutional dysfunction.

${ }^{54}$ See, e.g., Robert J. Cottrol \& Raymond T. Diamond, The Second Amendment: Toward an Afro-Americanist Reconsideration, 80 Geo. L.J. 309, 349-58 (1991). Nicholas Johnson's book provides the most comprehensive examination of the right to have arms and the defense of black communities. See NichOLAS JoHNSON, NEGROES AND THE GUN: THE BLACK Tradition of ARMS (2014); see also LANCE HILl, THE Deacons for Defense: ARMED Resistance IN THE CIVIL RightS MOVEMENT (2004); AKINYELE ORNOWALE UMOJA, We WILl SHOOT BACK: ARMED RESISTANCE IN THE MISSISSIPPI FREEDOM MOVEMENT (2013). 